\title{
Influence of Epidemic Situation on Employment of College Graduates and Informatization Countermeasures
}

\author{
Rui Huang*1 \\ ${ }^{1}$ SHU-UTS SILC Business School \\ Shanghai University \\ Shanghai, China
}

\begin{abstract}
The COVID-19 spread gradually throughout the country in the Spring Festival around 2020, leading to economic downturn and more severe employment situation in colleges. Multiple difficulties and challenges, such as the reduction of employment posts, the delay of graduation progress, the change of recruitment forms and the psychological anxiety of college students, lead to the huge employment pressure for college graduates. We can cultivate the comprehensive ability of students by means of informatization management, such as broadening employment channels, ensuring graduation on time, improving employment policies and rebuilding psychology of college students. In this way, the high quality of employment work in Colleges can be ensured. Scientific measures should be taken to deal with the impact of the epidemic on employment.
\end{abstract}

\section{INTRODUCTION}

The Corona Virus Disease 2019 (COVID-19) was the most serious public health emergency that China has encountered, with the fastest speed, the largest infection range and the most difficult prevention and control. It has disrupted the rhythm of economic operation. Economic activities create jobs. The "quality" and "quantity" of employment largely depend on the demand for graduates in the labor market. However, the epidemic situation brings difficulties and challenges to the realization of the annual economic and social development goals. Under the impact of the epidemic situation on economic growth, the "quality" and "quantity" of college graduates' employment will inevitably be affected, which brings great pressure to the employment work of college students. To deal with the impact of the epidemic situation, we should take decisive emergency measures and make long-term preparations. At present, the state is actively taking measures to implement more active employment policies to prevent large-scale unemployment risks. This means that college students who are about to enter the society are facing employment pressure as well as huge opportunities and challenges.

\section{THE IMPACT OF THE EPIDEMIC ON THE EMPLOYMENT OF COLLEGE GRADUATES}

\section{A. Reduction of jobs}

According to the "2020 Freshmen Spring Recruitment Trend Report" issued by Boss Direct Employment, as of March 31, 2020, the scale of recruitment demand for the corresponding graduates of enterprises has dropped by $22 \%$ year-on-year. The epidemic situation continues to make enterprises suffer economic losses and bear great business pressure. With the continuous delay of resumption time, enterprises must ensure the rights and interests of existing employees while stopping production and business, which leads to the increase of employment costs, the decline of operating profits and the difficulty of capital turnover, so that the demand for new jobs will inevitably sharply reduce. However, the number of graduates has reached a record high this year, as shown in Fig. 1. First, affected by the epidemic situation, the closure of small and medium-sized enterprises has resulted in a number of unemployed people who need to be re-employed. Second, the pressure brought by the transfer of studying abroad to employment. The rapid spread of the epidemic in western countries, such as the United States, Italy and France, has caused impact on the market. This is bound to change the plans of those in China who had planned to study abroad. These people either work in China first, then choose to study abroad, or choose to study in China, which will exacerbate domestic employment competition. Finally, the return of foreign 
employees from multinational corporations increases the competition for employment. The epidemic situation in China has been effectively controlled. Compared with the rapid spread of the epidemic abroad, China is the first country to restore normal economic and social life and maintain sustainable development vitality. The overseas business of multinational corporations is affected and the domestic business is developing normally. Therefore, it is more likely for multinational corporations to transfer foreign employees to China. This will inevitably reduce the number of jobs that multinationals are hiring in China. The contradiction caused by the shrinking of jobs and the increase in the number of graduates makes it more difficult for college students to find jobs.

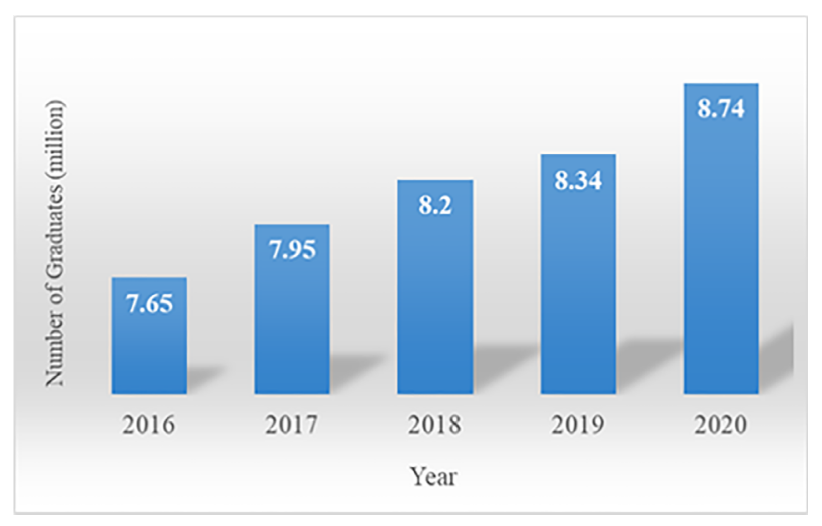

Figure 1. Number of graduates in recent five years.

\section{B. Delay of graduation progress}

Affected by the epidemic, the national education system novel coronavirus pneumonia prevention and control video conference stressed that we should conscientiously strengthen the awareness of positions. The school gate must be strictly controlled, without the approval of the school students are not allowed to return to school. Most graduates have already made clear plans for internship, employment interview and entry examination before winter vacation. However, these plans have been cancelled or shelved because of the epidemic. Engineering graduates were unable to enter the laboratory to carry out experimental work, making the graduation thesis writing more difficult. All of these have seriously delayed the normal graduation progress of college students.

\section{Change of recruitment form}

Affected by the epidemic situation, government departments at all levels of the country successively issued the epidemic prevention and control circular. Strengthen regional isolation and block the transmission of COVID-19 by means of tight containment. The Ministry of Education has made it clear that the on-site recruitment of colleges will be suspended during the epidemic period, and the online employment service will be vigorously promoted. This has caused great inconvenience to college students and employers who are used to the traditional offline recruitment form. On the one hand, many college students do not pay close attention to employment news. They still hold the hope of waiting for offline recruitment and cannot change their job-hunting thinking in time with the impact of the epidemic. It is difficult for them to accept online jobhunting in a period of time. On the other hand, job hunting links such as written examination, interview and practice are important means for employers to assess the ability and quality of college students in reality. However, the suspension of offline recruitment will directly lead to the inability of employers to effectively select truly suitable employees, thus affecting the accuracy of employers' recruitment and selection.

\section{Psychological anxiety of College Students}

Affected by the epidemic, the employment mood of most fresh graduates is relatively depressed. On the one hand, the epidemic prevention and control has led to prolonged unemployment and delayed hiring. Graduates cannot get a close understanding of the enterprises they like, which reduces the employment enthusiasm of graduates. On the other hand, most graduates are not ready for job hunting. Some inherent problems, such as the lack of basic literacy and self-confidence, make them have negative emotions and cause strong employment anxiety.

Some students are awed by difficulty in online interview and non-professional job application. It is easy to have anxiety and tension in the process of applying for a job, leading to poor interview performance and job failure. Some graduates have insufficient understanding of the employment situation during the new crown pneumonia epidemic. They still insist on pursuing jobs in popular fields such as government agencies, institutions, and state-owned enterprises. As the written examinations and interviews of relevant employers were cancelled or postponed by the epidemic, the smooth employment of graduates was affected.

\section{Response MeAsure}

\section{A. Broaden employment channels}

From the perspective of employment, the school should increase the efforts to carry out online and offline recruitment activities. To guide graduates to achieve diversified employment through new employment forms and flexible employment methods. With the help of online recruitment to expand the scale of publicity, so that more employers choose satisfactory talents, shorten the distance between employers and graduates. In addition to the above methods, guiding graduates to enlist in the army, participating in grass-roots employment programs such as special post plan, three supports and one support, and college student village officials are also effective countermeasures. Graduates in practice constantly experience skills and improve their personal ability, but also to find a better job to lay the foundation. In addition, colleges can hold educational lectures to encourage college students' innovation and entrepreneurship. Let students with planning and ability start their own businesses and give full play to their wisdom, ability and advantages. Under the support of the innovation and entrepreneurship policy of college students, 
entrepreneurship can drive employment and realize their life ideal.

From another point of view, further education can also be seen as a kind of employment. Colleges can adopt the method of expanding the enrollment index of graduate and doctoral students to drain college graduates. To adjust the unbalanced market of supply over demand, and relieve the employment pressure this year. Appropriate expansion of graduate students, especially doctoral students, will provide higher level talents for the society. At the same time, colleges can take the initiative to contact alumni and local cooperation units to explore further opportunities in industries such as the Internet, big data, artificial intelligence and new infrastructure. To provide guidance and service support for every graduate as much as possible, so as to increase the opportunities for further study.

\section{B. Guarantee graduation on time}

Colleges should strive to ensure the successful graduation of students who complete the training plan on time and meet the quality requirements of graduation thesis. Students who are really unable to graduate on time due to the impact of the epidemic may be allowed to extend the graduation period appropriately. According to the actual situation during the period of epidemic prevention and control, colleges should adjust the teaching schedule and do a good job in connecting all the links. Using Internet technology to improve the teaching mode, so as to promote the close combination of online teaching and students' autonomous learning. Colleges should adjust the practice mode and strengthen the individualized guidance for graduates. On the basis of ensuring the teaching effect, colleges should optimize the teaching arrangement to ensure the graduates finish their studies in time.

\section{Improve employment policy}

Expanding and promoting employment is an important direction of public financial investment. To ensure employment stability, we need to proceed from a fundamental economic perspective. Governments at all levels need to set up special funds, strengthen employment security, and transform national policies into long-term policies to support the production of small, medium and micro enterprises based on the actual development situation after the epidemic. Financial support policies that are more conducive to promoting employment should be implemented to help enterprises and college entrepreneurs broaden financing channels and increase credit. Encourage formal financial institutions to give preferential loans to them. Financial expansion needs to benefit many enterprises that really need capital, in order to play its role in driving employment growth and promoting economic vitality.

At present, the country implements online recruitment in all aspects, such as online publicity talks, online comprehensive evaluation and online interview. In view of these changes in recruitment forms, public employment service agencies can extend the time for receiving reports, signing employment agreement and registration procedures through fax, network and other ways for graduates to registration procedures. Colleges should actively improve the employment policy and simplify the submission procedures of graduation related materials. In addition, colleges should improve the way of file management. Extend the length of time the files are attached, allowing graduates to be attached to the school for two years.

\section{Psychological construction of college students}

Facing the impact of the epidemic situation and other uncertain factors, college students should face it calmly and adjust their anxiety psychology in time. Treat the employment pressure calmly, and actively make the next step planning. Facing up to the impact of the epidemic on the economy and society and the potential development opportunities. Make a systematic study and judgment on various risks of future employment, especially the development trend of future industries affected by the epidemic and the development progress of the industry in which one expects to work. Have sufficient psychological expectation for the possible risks and deal with them as early as possible. Graduates should give full play to their subjective initiative and reduce the risk caused by personal factors. Constantly improve employment skills, including professional quality, practical skills and exams preparation ability. Learn more from others and consult with experts on employment experience. Establish confidence in development and improve the ability to deal with risks. Learning how to freely face the camera and show their ability, which is related to the daily accumulation of personal literacy, more inseparable from repeated learning reinforcement. Therefore, instead of being afraid and worried about gains and losses, it is better to carefully sort out the current job search needs through the corresponding online vocational training. Make more adequate preparations for relevant modules such as resume production, interview skills, job-hunting etiquette and skill requirements, so as to win the "employment war" with excellent abilities.

\section{E. Build information-based employment platform}

The Ministry of education has clearly stressed the need to make full use of the new mode of "Internet plus employment". Colleges should transfer the focus of graduate employment work to the network position in time, and actively integrate all kinds of social resources. Qualified colleges can develop their own online recruitment platform. Colleges that do not have the conditions can cooperate with relevant enterprises to test and screen the online employment platform to find a suitable platform for their employment. In this way, a menu-style selection can be provided for the diverse needs of graduates. According to the graduates' own conditions and personality characteristics, intelligent supply and demand matching should be carried out. Especially during the COVID-19 outbreak, we need to ensure that online recruitment is unimpeded while offline recruitment is suspended. Colleges should actively connect with 
employers and change the way of negotiation between supply and demand. Carry out recruitment activities in the form of online video double selection meeting, air propaganda conference and short video recruitment. Colleges should organize graduates to make full use of the information platform to carry out job-hunting activities. Implement instant communication without meeting to solve difficult problems encountered in the recruitment process for enterprises and graduates. Pay attention to strengthening the support of online recruitment activities and the guarantee of software and hardware conditions. Actively try to establish a school-school alliance to achieve resource sharing and complementary advantages. Joint development of the employment market, and constantly improve and enrich the means of information services. Realize the full coverage of informatization in all work links to the greatest possible extent, and strive to improve informatization service capabilities. Relying on the new media information platform to create a "cloud employment" system to provide more accurate guidance for precision employment services.

\section{F. Establish accurate assistance mechanism}

According to the characteristics of students' physical and mental development, colleges should provide personalized employment guidance, psychological consultation and employment assistance for students. Tailor the employment plan for each graduate and accurately grasp the employment dynamics of graduates in real time. Colleges also need to use multi resources to establish a docking platform for school enterprise cooperation. Strengthen the docking of talent supply and demand in key areas, major projects, major projects and important fields. Further explore the employment opportunities created by the deep integration of the Internet, big data, artificial intelligence and the real economy, so as to support graduates to achieve multichannel employment through informatization. In addition, job hunting subsidies or rental housing subsidies should be provided to students with family difficulties. At present, affected by the epidemic situation, the employment cost of graduates is rising. For poor students from families, the expenses in transportation, accommodation and other aspects may exceed expectations and be difficult to fill. Colleges should timely understand the current situation of poor students' job hunting, give them financial assistance and emotional help, help them devote themselves to job hunting and find suitable positions.

\section{ConCLUSION}

The emergence of the epidemic could affect economic development in a certain period of time. However, new industries, new formats, new technologies and new occupations will continue to emerge after the epidemic. It is a social project of great importance to solve the employment problem of college students. At the same time, there are many factors affecting the employment of college students. The country, society, universities and other parties should work together to effectively solve the problem of graduate employment. At the moment, both opportunities and challenges coexist. No matter the country, universities or graduates themselves, they should seize the opportunities and face the challenges. Implement the employment policy at all levels and actively change the concept of employment. College graduates are not only job seekers today, but also future producers, entrepreneurs and job providers. In the current situation, graduates should be confident in the future. Pay close attention to the employment policies of government and recruitment information of enterprises. Keep close contact with schools and colleges. At the same time of polishing yourself, relax your mind and actively deal with the current situation, which will eventually overcome the difficulties and successfully enter the workplace.

\section{ACKNOWLEDGMENT}

The author is grateful to teacher Soh Lian Hong for proofreading this manuscript. The author thanks the Career Centre for supporting this work.

\section{REFERENCES}

1. Huang Wei. "The development of epidemic situation: the employment of college graduates is facing challenges". Employment of Chinese college students, 2020 (04): 9-11.

2. Li Hao. "Looking for a job in an epidemic situation requires a good attitude". Anhui Daily, 2020-05-19 (009).

3. Yue Changjun. "How does the epidemic affect the employment of college graduates". China Youth Daily, 2020-03-09 (08).

4. Ge Daokai. "Firmly win the employment battle of college graduates”. Jiangsu Education Daily, 2020-06-17 (001).

5. Zhang Jun. "Ensure the employment of college students under the new employment pattern". Guangming Daily, 2020-6-30 (15)

6. Wang Jingzhong. "The judgment of employment form of college graduates based on the analysis of supply and demand relations". China Higher education.2020(6)

7. Cai Hongjian. "When the job-seeking season meets the epidemic situation, how do college graduates find employment in 2020?". People's Forum, 2020 (Z2): 124-127.

8. Cai Hongbo. "Estimation of the impact of COVID-19 on current employment patterns in China" People's Forum, 2020 (9): 92-94.

9. He Leilei. "Opportunity in Danger: Thoughts on the Implementation of Remote and accurate Employment Guidance for College Students under COVID-19", Employment of College Students in China, 2020 (5): 16-18.

10. Li Ping. "Go all out to stabilize employment", China Labor Security News, 2020 (01): 17-19.

11. Bi Jingfu, Shen Weizhi. "Stabilizing enterprises is the first step to stabilize employment under the epidemic situation", United Daily, 2020 -03-11(03).

12. Wang Shuanghuang. "Employment psychology of College Students under the background of epidemic situation", Journal of Fujian Institute of Education, 2020 (04):78-80.

13. Mo Jie. "Actively respond to the employment examination under the epidemic situation", Guangming Daily, 2020-02-25(011).

14. Cheng Jie. "The impact of COVID-19 on the epidemic situation and countermeasures", China Development Observation, 2020 (Z2):40-42

15. Li Changan. "How to stabilize employment under the impact of epidemic situation”, Global Times, 2020-03-14(007).

16. Chen Jianwei, Lai Desheng. "Changes and Countermeasures of College Students' employment situation under the impact of epidemic situation", Employment of Chinese College Students, 2020(11),34-37.

17. Yu Qingfeng. "Reflections on the employment of college graduates during the period of epidemic prevention and control", Journal of Liaoning Communications College, 2020, 22(1), 5760 . 
18. Ju Binjie. "Construction and Reflection on the mode of precise employment assistance for college graduates", Henan Education (Higher Education), 2020(02):58-60.

19. Zhang Limin. "Online recruitment: colleges need to strengthen guidance", China Economic Times, 2020-02-26(2).

20. Yuan Yuan. "Strengthening employment stability through multi pronged approach", Xinhua Daily, 2020-02-29(1)
21. Zhao Ming. "Research on the Countermeasures of improving the employment quality of college students in China", Jiangsu Higher Education, 2019(10): 106-111.

22. Zhang Jie. "How to deal with the new employment trend of college graduates under the normalization of epidemic prevention and control", Guangming Daily, 2020-06-30(15). 